\title{
Human smuggling reconsidered: the case of Lesbos
}

\author{
Dina Siegel ${ }^{1}$
}

\section{Human smuggling - a complicated phenomenon}

Article 3(a) of the United Nations Smuggling Protocol defines migrant smuggling as a crime involving "the procurement, in order to obtain, directly or indirectly, a financial or other material benefit, of the illegal entry of a person into a State Party of which the person is not a national or a permanent resident". This definition underlines that human smuggling is a transnational crime, but the emphasis here is on economic gain, not on violence or other harm to the smuggled person's life, health or property. In the academic literature various authors have tried to narrow down the definition of the phenomenon. Kyle and Koslowski, for example, put forward the following definition of human smuggling: "an individual's crossing of a state's international border without that state's authorization and with the assistance of paid smugglers" (2011:4). Here again, no clear, direct victims are identified as an element in the definition. Attempts to clarify exactly what kind of crime is being committed in terms of victims, offenders and harm have rarely been successful. Human smuggling is still often linked to and confused with human trafficking, even though it is the aspect of exploitation that distinguishes the two phenomena.

In-depth historical and anthropological studies characterise human smuggling as a consensus between someone who, for a variety of reasons, cannot leave his or her country and/or enter another country on a regular basis and seeks help to be brought from one country to another; someone who is able to provide this type of assistance in return for payment, and/or someone (or several people) who can guarantee payment. The practice of

1 The author is Professor of criminology at the Willem Pompe Institute, Utrecht University, the Netherlands. 
human smuggling is also directly related to the practice of 'beating' the existing migration system. All over the world irregular border crossing or other forms of illegal migration have been a response to restrictive migration policies and the obstacles created by policy-makers and law enforcement.

Although we now know much more about the global practice of people smuggling, some authors maintain that empirical research on this phenomenon and the actors involved has remained scant (Zhang et al., 2018: 10), in contrast to the number of government reports and media stories on this crime of mobility. Many academic researchers and analysts have published critical studies on migration policies (Andreas, 2011) or on the morality of human smuggling (Aloyo and Cusumano, 2018), but these studies are mostly based on government data and media stories. Many ethnographers, on the other hand, have provided information on the root causes of migration and migrants' travel experiences, but not specifically on people smuggling (Spencer, 2004: 302).

This chapter will provide empirical knowledge on human smuggling by analysing my ethnographic data on the smuggling of migrants from Turkey to the Greek island of Lesbos and by giving a voice to the people who underwent the process. This will offer some food for thought with respect to the prevailing views on human smuggling in the academic and public debate.

\section{Methodology}

I spent the summer of 2017, from the end of May until the middle of September, on Lesbos to study the consequences of the so-called refugee crisis as experienced by migrants, local islanders, NGO representatives and EU officials. My ethnographic research methods included participant observation and 66 open interviews with asylum seekers, local islanders and representatives of government organisations, NGOs and law enforcement. Human smuggling, the focus of the present chapter, was only one aspect of a larger study I completed in 2019, titled Dynamics of solidarity - consequences of the 'refugee crisis' on Lesbos (Siegel, 2019).

The extended case method was used to collect information from various sources (multi-site and multi-level ethnography) and it included different 104 
sub-cases which provided many pieces of the puzzle needed to compose a complete picture of the situation in all its complexity (Marx, 1976). Human smuggling was one of these pieces and it raised a number of questions about the meaning of crimes of mobility.

\section{Research question}

During the 'refugee crisis' of 2015-2017, Lesbos, an island in the Aegean Sea close to Turkey, became the most-discussed migrant destination in the international media. Lesbos is one of the EU's 'hotspots', where migrants are identified and given the opportunity to apply for asylum in Europe. The island's infamous camp, Moria, where thousands of migrant are currently living in precarious conditions, has become a symbol of the EU's failing migration policy (Siegel, 2018; Siegel, 2019).

Reading media and government reports on the mass migration to Lesbos made me wonder why so many migrants were apparently willing to pay thousands of Euros to members of organised crime networks (i.e. human smugglers) to organise their trip from Turkey to Lesbos, only $12 \mathrm{~km}$ away. Why did they come at all, knowing that they ran the risk of either drowning in the stormy sea or being caught by the Turkish Coast Guard and forcibly returned? Why did these people keep trying to make the crossing to Lesbos while being aware - as they must have been - of the conditions in reception centres such as camp Moria, whose inhabitants were lacking basic needs and were suffering from illnesses, a general lack of hygiene and internal fights between different ethnic groups of migrants? They also must have known that it could take months or even years for a decision to be reached on their asylum application and that it was more than likely that they would be denied entrance to Europe. What was the role of people smugglers in their 'adventures' and how did these migrants and their helpers experience the practice of human smuggling? 


\section{People smugglers in the public discourse}

There are significant differences between law enforcement sources and empirical research on the phenomenon of human smuggling with respect to organised crime activities, the brutality of criminal smugglers and the vulnerability of migrant victims. Governmental and EU reports are often contradicted by ethnographic studies drawing attention to individual initiatives, community assistance and the agency of migrants themselves. The stereotype of smuggled persons as 'victims' of organised crime depicted in official reports is countered by stories (documented in academic publications) of the 'winners' who made it to their desired destination. The image of people smugglers, on the other hand, is a lot less clear-cut.

\section{Smugglers as criminals}

Most official documents tend to portray human smugglers as criminals who "exploit the desperation and vulnerability of migrants" (Europol, 2016). On the basis of this assumption, Europol launched the European Migrant Smuggling Centre to "pro-actively support EU Member States in dismantling criminal networks involved in organizing migrant smuggling". Official reports on human smuggling indicate that "in 2015 alone, criminal networks involved in migrant smuggling are estimated to have had a turnover of between EUR 3-6 billion. This turnover is set to double or triple if the scale of the current migration crisis persists in the upcoming year" (Europol, 2016:2). And "more than $90 \%$ of migrants are facilitated to the EU, mostly by criminal networks" (ibid: 4). Europol predicted that these criminals would continue to expand their activities, using vulnerable migrants for sexual and labour exploitation in the coming years "unless decisive action is taken" (ibid:13). Human smuggling is hereby equated to human trafficking, with the emphasis on the exploitation and victimhood of migrants. In the same line, the United States State Department refers to smuggled people as being “. . . extremely vulnerable to human trafficking, abuse and other crimes, as they are illegally present in the country of destination and often owe large debts to their smugglers" (U.S. State Department, 2017:1). In this document the line between smuggling and trafficking is not only blurred, but practically obliterated. 
The European Commission's starting point is that "ruthless criminal networks organise the journeys of large numbers of migrants desperate to reach the EU. They make substantial gains while putting the migrants' lives at risk" (European Commission, 2015:1). These smugglers allegedly treat migrants not as human beings, but as goods, similar to the drugs and firearms that are transported along the same routes. Although the document's authors admit that there are no data on the profits human smugglers around the world are making with their criminal activities, "isolated cases show that these are substantial" (ibid). One of the recommendations in the EU Action Plan against human smuggling 2015-2020 is to raise awareness of the risks of human smuggling to prevent potential victims from embarking on a dangerous journey and putting their trust in cruel and deceitful smugglers who have approached them through social media (ibid: 6).

Similar 'facts' are presented on the official website of the United Nations Office of Drugs and Crime (UNODC), which explains that human smuggling is a transnational crime, in the course of which migrants are subjected to grave human rights abuses. The criminals have "tremendous power, while the migrants are left vulnerable" (UNODC, 2019). The potential risks are specified: even if the journey is consensual, it can still turn into a nightmare. "During the trip, people might be squeezed into exceptionally small spaces in trucks or onto unseaworthy boats in order for smugglers to maximize their 'cargo'. Migrants might be raped or beaten en route or left to die in the desert. Once they reach their destination, many find that they (or their families) are the victims of blackmail or debt bondage. The latter can involve migrants paying huge sums of money to criminals in order to settle near-impossible levels of debt out of fear of violence or fear of being deported by the authorities, which can result in them becoming victims of human trafficking" (ibid). People smuggling can also fuel corruption and organised crime. "There is evidence suggesting that, with the ever-growing interdependence of the global economy, the involvement of criminal groups in the smuggling of migrants is on the rise" (ibid). However, no concrete empirical data or references to this 'evidence' are provided and the links in the text all refer to other UNODC reports.

This image of the smuggler does not only appear in official reports. Various researchers have reinforced the negative stereotype of human smugglers as violent, evil men (Kyle and Scarcelli, 2009) who have no qualms about letting their victims/customers suffer or even die (Human 
Rights Watch's Dispatches, 2014). Human smugglers are often presented as members of criminal organisations (Kaizen and Nonnema, 2007; Narli, 2006; Saha, 2007; Schloenhardt, 2002; UNODC 2015; Sciopi and Ionescu, 2016), as kidnappers (Walser, Baker McNeill and Zuckerman, 2011) and/or as synonymous with human traffickers (Aronowitz, 2001; Bilecen, 2009; Lintner, 2002).

In the Oxford Handbook of Organised Crime (Paoli, 2014), the categories of human trafficking and human smuggling are discussed in one breath (Kleemans and Smit, 2014). Fortunately, the authors acknowledge that a distinction must be made and that there is growing concern about the opposing views on the difference between the two phenomena, as this creates obstacles for empirical research (ibid: 397 ). However, the real problem is not with the research, as in most cases criminologists know (or are expected to know) how to conduct independent, unbiased research. The real problem is with the application of the incorrect and generalised conclusions of some of the above-mentioned reports to policy-making, as this may lead to stigmatisation, wrongful accusations and damage to the interests and humanitarian protection of migrants (Tazzioli, 2016).

\section{The positive image of a smuggler}

Instead of recycling law enforcement data and the findings of so-called migration experts, empirical criminological research has focused in recent years on the activities and business organisation of people smuggling around the world, based on interviews with those involved in it (DiNicola and Musumeci, 2014; Staring, 2012; Zhang, 2008; Van Liempt, 2010; Bilger, Hofmann and Jandl, 2006).

Traditionally the phenomenon of irregular migration is deeply rooted and embedded in communities (Zhang, 2008) where social ties and trust relationships exist as these aspects are crucial to its success. In many communities, relatives, close friends, neighbours and co-villagers all make a vital contribution to facilitating the journey and guaranteeing payment. Zhang and Chin showed in their studies how entire villages in China were involved in planning and supporting smuggling operations (Zhang and Chin, 2002). Majid emphasised that community and family ties are key factors in the smuggling of people from Afghanistan and Somalia (Majid, 
2018). Baird shows that trust is the basis of the relationship between migrants and smugglers in Turkey (Bairda, 2016) and Sanchez shows in her research how trust is based on 'socially cemented ties' in Mexico (2015:17). The social embeddedness of human smuggling as a collective practice is emphasised by Mengiste (2018) in the context of Eritrean and Ethiopian migrants. According to Achilli, the relationships between smugglers and migrants are "rich in solidarity and reciprocity and grounded in local notions of morality" (Achilli, 2018: 77). Chinese migrants in the US even consider their smugglers as philanthropists (Zhang, 2007: 89).

The image of the smuggler that emerges from these empirical studies is that of a family member, a friend or an acquaintance who can arrange a migrant's journey and make their dream come true. Maher describes how in Senegal the smuggler is considered as a friend, protector and guide (Maher, 2018). He is a member of the community, someone who enjoys the respect and trust of other migrants. Trust, reputation and personal relationships are thus key factors in understanding migrant smuggling.

Members of the community usually consider people smuggling as a legitimate enterprise rather than a criminal activity and regard smugglers as well-connected and knowledgeable entrepreneurs. They view illegal people smuggling as a strictly rational business with its own specific risks, just like any other business, and they 'silence morality' (Bauman, 2000: 29). Not all smugglers appear to be equally experienced and successful and sometimes they fail to complete their mission or make serious and even fatal mistakes during the trip. But in many cases, mainly those that are not registered in police statistics and do not attract media attention, the smuggling operations are successful. These successes reinforce the smuggler's positive image and function as an informal advertisement for recruiting new clients.

The smuggler as an information and service provider is also often mentioned in the literature. Austrian research revealed that smugglers gave migrants information about the legal situation in the destination country and practicalities on how to deal with the authorities, even though this information was not always correct (Bilger, Hofmann and Jandl, 2006). In his research on smuggling along the Mexico-US border, David Spener introduced the term 'coyote', meaning professional service providers who help migrants to cross the border (2004). These coyotes appear to 'make sure that disasters do not befall the migrants they transport' (Spencer, 2004: 
310). Migrants usually choose coyotes who have already proven that they are capable of organising a trip by safely transporting other family or community members (ibid: 311 ). Migrants perceive their know-how and value it as a guarantee for the success of the operation.

One of the main reasons why human smugglers are presented as criminals in the media and the public debate is that they profit from those who use their services. The question is whether this should be considered a problem. As Castells and Portes (1989) argue, the migrant smuggler is an actor engaged in the informal economy, something that usually happens when state institutions fail to provide regulations. Other authors have similarly emphasised that human smuggling is a market and smugglers are economic actors filling a niche that governments cannot provide or regulate (Di Nicola and Musumeci, 2014; Zhang, 2008). Achilli (2018) takes this a step further in his analysis, arguing that smugglers are not driven solely by profit, but mainly by morality and religious duties, when they become involved in this illicit enterprise.

This type of smuggler appears to contradict the image of smugglers as cruel, rapacious criminals who knowingly send people to their death on the open seas that is propagated by the media and in the public and political debate. This discrepancy in the representation of human smuggler in public debate is persistent. Perhaps anti-smuggling officials are turning a blind eye to the narratives in the academic literature, or maybe the researchers are misinterpreting what they see and hear during their research. The only way to understand this discrepancy is to go to the field and communicate with the actors involved in human smuggling.

\section{Human smuggling on Lesbos}

I found the same discrepancy between positive and negative views on human smuggling during my fieldwork on Lesbos. During this period there were reports in the local media that several smugglers had been arrested. It was striking that these smugglers were not bringing migrants from Turkey to Lesbos, but had been trying to smuggle migrants from the island to the mainland or even back to Turkey on private boats or the ferry. One attempt, widely reported in the local media, involved a person who was arrested while trying to smuggle four migrants onto the ferry on his motorcycle 110 
(Lesvosnews.net, 24 July, 2017). There were, however, no reports of human smuggling from Turkey to Lesbos, as there had been in previous years. In 2015-2017 human smuggling activities to Lesbos were frequently mentioned in local and social media and police reports. In this period this mainly involved the smuggling of migrants from Turkey to Lesbos.

During my fieldwork I could distinguish three types of human smuggling. Firstly, activities shifted from smuggling people from Turkey to Lesbos to smuggling them from the island to the Greek mainland. Migrants arriving on Lesbos became 'locked' there, as according to the Dublin regulation they have to be registered in the first EU country in which they arrive, which was Greece in this case. They had to apply for asylum there, even though their real destination was usually somewhere else in Europe. Those who did not want to apply for asylum on Lesbos tried to disappear into illegality (a difficult feat on an island) and escape to mainland Greece, from where they hoped to continue their journey to West Europe illegally on land.

Secondly, migrants who had already applied for asylum on Lesbos and realised that they had no chance of getting it, or who could no longer tolerate the long wait for an asylum decision, especially in view of the difficult conditions in the camps, tried to return to Turkey with the help of smugglers in order to look for other possibilities for reaching Europe. In principle, they could tell the authorities that they wanted to be voluntarily deported back to Turkey, but the deportation process (bureaucratic and physical preparations) could take a long time, which obviously they did not want to waste. Approaching smugglers to bring them back was a much swifter solution.

Last, but not least, there were the still regular arrivals of boats carrying migrants to Lesbos. The smugglers who had arranged their trip did not travel with them, remaining in Turkey and issuing instructions by phone or text. Usually their boats were found by Frontex, the Hellenic Coast Guard or activist ships (such as Sea Watch), who rescued them and brought them ashore.

On the basis of police and Frontex information and stories of migrants, activists and academic researchers (all personal communication in the summer of 2017), human smugglers on Lesbos could be divided into several categories. 
The local police mainly mentioned organised crime networks, especially Turkish and Albanian smuggling groups. These groups appeared to be particularly active at the start of the 'refugee crisis'. According to police sources, these violent criminal smugglers had no compunction about sending migrants out to sea on defective rubber boats without providing them with usable life jackets. In the north of Lesbos, the 'cemetery' of thousands of abandoned life-jackets, many in children's sizes and some with visible warnings in different languages that they should not be used for swimming, still serves as a grim reminder of the dangers of the migrants' journey. Another cemetery, not far from the capital Mytilene, where the 'unknown' migrants are buried whose bodies were washed ashore on the island, is held up as proof by politicians and media for the involvement of ruthless criminal smuggling gangs who are only focused on their own profits and do not care for the safety of their clients.

A second category consisted of immigrants from the same country of origin, especially Syrians, Afghans and Iraqis, who were smuggling their compatriots and were usually mentioned by migrants themselves.

According to Frontex, local police and some migrants, the third category consists of so-called 'guest-smugglers' who had come to Turkey from other countries, such Russia, Georgia and Bulgaria, and successfully obtained the contacts and know-how needed to conduct their operations.

Members of non-governmental organisations and other charity groups were also considered as human smugglers, mainly by the local police and residents. 'Occasional smugglers' included tourists and fishermen was also mentioned by police and local islanders.

All these categories can be considered as human smugglers if one applies the UN or EU definition. Some were involved in the entire process, from planning and organising to facilitating the journey. Others, such as 'guest-smugglers', were brokers, who connected migrants with 'real' smugglers, or arranged false documents. Others, such as members of NGOs or tourists or local islanders facilitated some parts of the journey by providing migrants with transport, food or shelter. The latter aspect of smuggling will be discussed later in this article as an example of crimes of solidarity. 


\section{Making profits on migrants?}

According to a Hellenic Police respondent: "In the last few years, a lot of smugglers were caught. There is still smuggling going on this summer, but less". He attributed the decline in the arrests of smugglers to the fact that smuggling had become less profitable: "the prices are very low now, between 300-500 euros". He explained that the prices had gone down because there were fewer migrants who wanted to be smuggled than in the previous years, especially in 2015, when the crisis was at its peak and thousands of people arrived on the island.

The modus operandi had also changed: "The smugglers do not accompany the refugees; they teach them how to operate a boat and send them out alone. The smugglers are mostly Turkish, but also Syrian, Moroccan and Algerian. The problem of fake documents is huge, especially for minors. The people who make them are their own nationals".

This information about smugglers provided by a police officer, shows a typical business-oriented operation method: prices are fixed according to the demand and opportunities created by migration. The decrease in demand for their services means a decrease in the profits. This observation definitely contradicts the prevailing idea that human smugglers make huge profits on migrants, or that they force them to pay exorbitant prices.

It is not human smuggling, but migration in general that can create an opportunity for local people to earn sometimes large amounts of money. One example of such an opportunity is that of the taxi drivers on Lesbos in 2015, when thousands of migrants who had landed on the north of the island needed transport to the south-east port of Mytilene in order to continue their journey. The local authorities refused to arrange bus services for the newcomers and this provided the taxi drivers with a golden opportunity to charge excessive rates (around 300-400 euros) for a $70 \mathrm{~km}$ trip. In 201516 , the price of daily goods and services, such as food, drinks, using the toilet or charging your telephone battery was hiked up by local restaurant owners and ordinary islanders, who saw an opportunity to earn money from the daily needs of newly arrived migrants. They, however, were not viewed as human smugglers: they were just trying to make a bit out of these migrants. The latter were victims of a rip off by locals, not by some bad ruthless smuggler as the policy papers depict. 


\section{The good smuggler?}

All of my migrant respondents told me that they had used the services of smugglers and were convinced that they would not have been able to reach Europe without them. The relationship between smugglers and migrants was primarily based on a financial agreement, but often it involved more than just money. One respondent told me that his smuggler had tried to transport him four times: three times the boat had been caught by the Turkish Coast Guard and returned to the Turkish shore. The smuggler never asked for more money, even when the boats were confiscated each time they were caught and he actually lost money on the venture. Instead he kept trying to smuggle the migrants until he succeeded. According to my respondent: "he promised to bring me to Greece and he kept his promise". According to another respondent, his smuggler knew that he could not afford to pay him much, so he agreed to smuggle him for less money than the others and his two young children for free.

Another migrant trusted one specific smuggler because of the positive experiences his brother and his family had had with him earlier that month. Successes serve as a positive advertisement and personal recommendations by family members or friends can enhance a smuggler's reputation. This smuggler was careful and delayed the boat's departure several times because of bad weather conditions.

In these stories, the smuggler came across not as a callous money-making machine but as a helpful and understanding person, who was considerate of individual problems and committed to bringing people to the next stop of their destination.

I also heard several times that smugglers helped migrants to decide on a better destination for their customers. When stories about the overcrowded camps on Lesbos started to dominate media headlines, smugglers advised migrants to travel to other islands, such as Kos or Samos. One respondent told me that his smuggler advised him to travel to Chios as there were fewer migrants there, meaning shorter waiting times for the asylum decision. When my respondent refused because he wanted to reunite with his wife and children on Lesbos, the smuggler sent him there. According to my respondent, the smuggler "was thinking what would be better for me, but I was the one who decided where to go, and he did what I asked". This 
example at least is at odds with the stereotype of victimized migrants who have no 'agency' and are manipulated by smugglers.

\section{Human smuggling out of solidarity}

Although facilitating irregular migration is not included in the definition of human smuggling, it is often associated with it. Article 1 of the 'Facilitators Package', composed of Directive 2002/90/EC, establishes a common definition of the offence of facilitating unauthorized entry, transit and residence, as does Framework Decision 2002/946/JHA on the strengthening of the penal framework to prevent the facilitation of unauthorised entry, transit and residence (European Commission, 2015). Although no financial profit is mentioned in this legislation, it includes a so-called 'délit de solidarité'. Many Europeans have been accused of this delict during the migrant crisis, according to the media reports.

Rozakou (2016) described how people were arrested on Lesbos for assisting migrants. The most dramatic case was in January 2016, when the Greek police pressed charges carrying prison sentences of up to 10 years against a group of Spanish lifeguards for towing a stranded dinghy with 51 refugees on it near Lesbos (Ekathimerini.com, January 14, 2016).

According to local police officers, several NGOs intended in recent years to facilitate the smuggling of migrants to Lesbos and there was evidence of contact between smugglers and NGOs, whereby the latter were given the precise location of the boats and other information so that they could meet migrants before the Greek Coast Guard found them. This was denied by my respondents from NGOs, who argued that they had no links with smugglers and were "operating only out of humanitarian purposes". The NGO members claimed that these accusations are part of a political campaign aimed at getting rid of NGOs on the island. Supposedly, NGOs are no longer needed as the 'refuge crisis' officially came to an end in March 2016 when the EU-Turkish agreement was signed and the authorities assumed control of migrants on the Aegean islands. In 2016-2017 various NGOs in other countries were accused in the media of cooperating with criminal human smuggling networks. Members of Médecins Sans Frontières, for example, were accused by Frontex of colluding with criminals and being "responsible for more deaths at sea" (Sigona, 2017). 
Most of my respondents were not aware that they were committing a crime by helping migrants; they had never heard of these EU laws and they could not identify themselves with criminal human smugglers and members of organised crime who harm their victims or exploit them for profit.

Both international volunteers helping migrants on Lesbos and local people giving migrants food and dry clothes were faced with a dilemma as their desire to help the needy was in direct contravention of their duty to obey the law, which forbade any such assistance. As a local resident explained to me:

"These poor people need my help, and I want to help, but my government prohibits me from doing this. What shall I do: follow my heart or follow my brain, because I don't want to go to prison?"

\section{Human smuggling reconsidered}

When there is such a huge discrepancy between official reports and accounts given by respondents in different studies on smuggling, including the present one, the effect of criminalising human smuggling in order to combat 'organised crime' must be doubted. It can harm individuals who facilitate illicit travel, and sometimes the punishments may seem highly disproportionate (Weber and Grewcock, 2012). Continuing to consider human smuggling as a crime cannot solve the more important problems of the recent migration. Human smugglers, labelled as criminals, have become scapegoats for inefficient migration policies around the world. It is they who are blamed for all the misery at sea, not the EU officials who are failing to look for root causes and solutions in the migrants' countries of origin and who are neither willing nor able to give them a decent reception in Europe. However, as many empirical studies have shown, 'cracking down on smugglers' does not deter migrants from trying to reach Europe. Human smuggling is a response to the increase in border controls and restrictive legislation. In the recent crisis in migration policies in the EU when hundreds of thousands of people were fleeing war, ethnic conflict or economic misery, human smuggling was unavoidable. Humanitarian assistance is also an old and unavoidable phenomenon, as there have always been people prepared to break the law in order to save the lives of others. 
The criminalisation of both human smuggling and facilitating irregular migration must therefore be reconsidered. Empirical research from all over the world has revealed plenty of negative consequences of such criminalisation.

The idea of reconsidering human smuggling as a criminal activity is not new. Smuggling is already being discussed in academic literature as a 'travel business' with 'service providers' (Zhang, 2007), and as a transnational service industry' (Bilger, Hofmann, and Jandl, 2006) with specific tasks assigned to 'brokers', 'fixers', or 'pushers' (Berg and Tamagno, 2013; Gammeltoft-Hansen and Sorensen, 2013; Lucht, 2013). This brokerage can be viewed as a business with customers to "shape transactions between migrants and smugglers in ways that are highly pronounced in travel and transit" (Ahmad, 2011, p. 7).

Regulation and acceptance of the historical fact that people have always been moving from one place to another in order to escape misery, be it political, social or economic and to search for better perspectives and opportunities could provide a real alternative to the failing struggle against alleged 'organised networks' of human smugglers. The prevailing stereotypes of cruel and greedy criminals sending their victims to their deaths continues to persist: it is such a convenient and politically accepted concept in policy papers, certainly if combined with 'organised crime'. The tragic media images of accidents at sea, the governmental reports and often exaggerated estimations of harm and victims in addition to the statements issued by moral entrepreneurs who have never talked to either smugglers or migrants make it more difficult for policy-makers to open their mind and search for better definitions and legislation for this phenomenon.

At the beginning of this chapter, I asked why people use the services of criminals. During my fieldwork I realised that human smugglers to Lesbos were not considered as criminals, at least not by the migrants who had been smuggled. On the contrary, the smugglers were seen as important helpers who had made it possible for them to fulfil their dream of reaching Europe. I also realised that there are many types of smugglers, ranging from the stereotypical images of organised criminals, as they are perceived by the police, to friends, compatriots, and even members of NGOs. Generalising these types and groups does not help us to understand or respond to this phenomenon. Political decision making must never rest upon abstract, im- 
precise knowledge. Empirical research, therefore, is vital for decision makers. Human smuggling (including crimes of solidarity) should be regulated, de-criminalised and recognised as an important factor facilitating migration.

\section{References}

Achilli, L., The "good" smuggler: The ethics and morals of human smuggling among Syrians. In: Migrant smuggling as a collective strategy and insurance policy: views from the margins. The ANNALS of the American Academy of Political and Social Science, 2018, 676 (1), p. 77-97.

Ahmad, A.N., Masculinity, Sexuality and Illegal Migration: Human Smuggling from Pakistan to Europe. Farnham, UK and Burlington, VT: Ashgate, 2011.

Aloyo, E. and E. Cusumano, Morally evaluating human smuggling: the case of migration to Europe, in: Critical Review of International Social and Political Philosophy, 2018, on:

www.tandfonline.com/doi/full/10.1080/13698230.2018.1525118

Andreas, P., The transformation of migrant smuggling across the US-Mexican border. In D. Kyle and R. Koslowski (eds.) Global human smuggling. comparative perspectives. Baltimore: The John Hopkins University Press, pp.107-25, 2011.

Aronowitz, A., Smuggling and trafficking in human beings: the phenomenon, the markets that drive it and the organisations that promote it. $E u$ ropean Journal on Criminal Policy and Research, 2001, vol. 9, No. 2.

Baird, Th., Human smuggling in the Eastern Mediterranean. London: Routledge, 2016.

Bauman, Z., Modernity and the Holocaust. Ithaca: Cornell University Press, 2000.

Bilecen, B., Human smuggling networks operating between Middle East and the European Union: evidence from Iranian, Iraqi and Afghani migrants in the Netherlands. COMCAD Working Paper No. 62. Bielefeld: Centre on Migration, Citizenship and Development, 2009. 
European Commission, Communication from the commission to the European Parliament, the Council, the European Economic and Social Committee and the Committee of the regions EU Action Plan against migrant smuggling (2015 - 2020), Brussels, 27.5.2015 COM(2015).

Human Rights Watch Dispatches, J. Sunderland, 'A heinous act, more deaths on the high seas' (September 16), 2014 on:

https://www.hrw.org/news/2014/09/16/dispatches-heinous-act-moredeaths-high-seas.

Kaizen, J. and W. Nonnema, Irregular migration in Belgium and organised crime: an overview. International Migration, 2007, vol. 45, no. 2.

Kleemans, E. and M. Smit, Human smuggling, human trafficking, and the exploitation of sex industry. In L. Paoli, (ed.) The Oxford Handbook of Organised Crime, Oxford: Oxford University Press, pp. 381- 401, 2014.

Kyle, D. and R. Koslowski (eds.), Global human smuggling. comparative perspectives. Baltimore: The John Hopkins University Press, 2011.

Kyle, D. and M. Scarcelli, Migrant smuggling and the violence question: evolving illicit migration markets for Cuban and Haitian refugees. Crime, Law and Social Change, 2009, vol. 52, No. 3.

Lintner, B., Illegal aliens smuggling to and through Southeast Asia's Golden Triangle. In: Nyiri. P and I. Rostislavovich (eds.) Globalizing Chinese Migration: Trends in Europe and Asia, Aldershot, Hampshire: Ashgate, 2002.

Maher, S., Out of the West Africa: Human smuggling as a social enterprise. In: S. Zhang, G. Sanchez and L. Achilli (eds.) Migrant smuggling as a collective strategy and insurance policy: views from the margins. The ANNALS of the American Academy of Political and Social Science, 2018, 676 (1), pp. 36-56.

Majid, N., Community dimensions of smuggling: the case of Afghanistan and Somalia. In: S. Zhang, G. Sanchez and L. Achilli (eds.) Migrant smuggling as a collective strategy and insurance policy: views from the margins. The ANNALS of the American Academy of Political and Social Science, 2018, 676 (1), pp. 97-113.

Marx, E., The Social Context of violent Behaviour. A Social Anthropological Study in an Israeli Immigrant Town. London, Henley and Boston: Routledge \& Kegan Paul, 1976. 
Mengiste, T.A., Refugee protections from below: Smuggling in the EritreaEthiopia context. In: S. Zhang, G. Sanchez and L. Achilli (eds.) Migrant smuggling as a collective strategy and insurance policy: views from the margins, The ANNALS of the American Academy of Political and Social Science, 2018, 676 (1), pp. 57-76.

Narli, N., Human trafficking and smuggling: the process, the actors and the victim profile. In N. Narli, (ed.) Trafficking in persons in South East Europe - a threat to human security, Vienna: National Defence Academy; Istanbul, Center for Strategic Research, 2006

Paoli, L. (ed.), The Oxford Handbook of Organised Crime. Oxford: Oxford University Press, 2014.

Rozakou, K., Crafting the volunteer: volunteer associations and the reformation of sociality. Journal of Modern Greek Studies, 2016, vol. 34, no.1, pp. 79-102.

Saha, K.C. Smuggling of Indian citizens: preliminary findings. Journal of Immigrant and Refugee Studies, 2007, vol. 5, No. 1.

Sanchez, G.. Human smuggling and border crossings. London: Routledge, 2015.

Schloenhardt, A., Organised crime and migrant smuggling: Australia and the Asia-Pacific, Research and public policy series, No. 44. Canberra: Australian Institute of Criminology, 2002, on: www.aic.gov.au/en/publications/current\%20series/rpp/41-60/

Sciopi, O. and A. Ionescu, Migrants' smuggling is knocking at the danube's door. Threats at the Romanian state border. Journal of Danubian Studies and Research, 2016, vol. 5. No.2, pp. 320-332.

Siegel, D., Crimes of solidarity in times of a migrant crisis. In D. Siegel and V. Nagy (eds.), The migration crisis? Criminalization, security and survival. The Hague: Eleven International Publishing, pp. 243-264, 2018.

Siegel, D., Dynamics of Solidarity. Consequences of the 'refugee crisis' on Lesbos, The Hague: Eleven International Publishing, 2019.

Siegel, D. and V. Nagy (eds.), The Migration Crisis? Criminalization, security and survival. The Hague: Eleven International Publishing, 2018.

Sigona, N., NGO's under attack for saving too many lives in the Mediterranean. The Conversation, March 29, 2017.

Spener, D., Mexican migrant-smuggling: a cross-border cottage industry. Journal of International Migration and Integration / Revue de 
l'intégration et de la migration international, 2004, Vol. 5 (3), pp. 295320.

Spener, D., Global Apartheid, Coyotaje, and the Discourse of Clandestine Migration: Distinction between Personal, Structural and Cultural Violence. In: Kyle, D. and R. Koslowski (eds.), Global Human Smuggling. Comparative Perspectives. Baltimore: The John Hopkins University Press, pp. 157-185, 2011.

Tazzioli, M., Border displacements. Challenging the politics of rescue between Mare Nostrum and Triton. Migration Studies, 2016, 4(1), pp. 119.

UNODC, Transnational crime. Human smuggling, 2019, on: https://www.unodc.org/toc/en/crimes/migrant-smuggling.html

U.S. State Department, Human trafficking and human smuggling. Understanding the difference, Washington, DC: Office to Monitor and Combat Trafficking in Persons, U.S. State Department, 2017.

Walser, R., J. Baker McNeill, J. Zuckerman, The human tragedy of illegal immigration: greater efforts needed to combat smuggling and violence. Backgrounder, 2011, No. 2568 June 22, pp. 1-18.

Zhang, S., Smuggling and trafficking in human beings: All roads lead to America. Westport, CT: Praeger, 2007.

Zhang, S., G. Sanchez and L. Achilli (eds.). Migrant smuggling as a collective strategy and insurance policy: views from the margins. The Annals of the American Academy of Political and Social Science, 2018, $676(1)$. 